ANALYSIS

\title{
The environmental effect of car-free housing: A case in Vienna
}

\author{
Michael Ornetzeder ${ }^{a}$, Edgar G. Hertwich $^{b, *}$, Klaus Hubacek $^{c}$, Katarina Korytarova $^{d}{ }^{,}$Willi Haas $^{e}$ \\ anstitute of Technology Assessment, Austrian Academy of Sciences, Strohgasse 45/5, 1030 Vienna, Austria \\ bepartment of Energy and Process Engineering and Industrial Ecology Programme, Norwegian University of Science and Technology, \\ 7491 Trondheim, Norway \\ 'Sustainability Research Institute, School of Earth and Environment, University of Leeds, Leeds LS2 9JT, UK \\ ${ }^{\mathrm{d} C e n t r a l ~ E u r o p e a n ~ U n i v e r s i t y ~(C E U), ~ E n v i r o n m e n t a l ~ S c i e n c e ~ a n d ~ P o l i c y ~ D e p a r t m e n t, ~ N a d o r ~ 9, ~ H-1051 ~ B u d a p e s t, ~ H u n g a r y ~}$ \\ ${ }^{\mathrm{e}}$ The Department of Social Ecology, Institute of Interdisciplinary Studies of Klagenfurt University (IFF), Vienna, Austria
}

\section{A R T I C L E I N F O}

\section{Article history:}

Received 3 May 2006

Received in revised form

22 March 2007

Accepted 20 July 2007

Available online 4 September 2007

\section{Keywords:}

Theme housing

Car sharing

Sustainable consumption

Household environmental impact

(HEI)

Input-output analysis

Life-cycle assessment (LCA)

National accounting matrices

including environmental accounts (NAMEA)

Transportation

Urban planning

\begin{abstract}
A B S T R A C T
A case-control study of the car-free model housing project in Vienna was conducted to evaluate whether people living in this settlement have more 'sustainable lifestyles' than people living in comparable buildings in Vienna. Another aim was to identify the lifestyle characteristics and household activities which significantly influence the environmental impact of the residents of the car-free housing project and a control group. The control group, referred to as the reference settlement, was chosen from a nearby building complex, with similar characteristics, but without the car-free feature. Household consumption patterns were estimated based on interviews in combination with data from the Austrian consumer expenditure survey and the national accounts. The evaluation of household environmental impacts uses emissions estimates from the Austrian national accounting matrices including environmental accounts and data from life-cycle assessments. Households from the car-free settlement have substantially lower environmental impacts in the categories of ground transportation and energy use; their $\mathrm{CO}_{2}$ emissions of these two categories are less than $50 \%$ of those living in the reference settlement. The households in the car-free settlement have somewhat higher emissions in the categories air transport, nutrition, and 'other' consumption, reflecting the higher income per-capita. As a result, the $\mathrm{CO}_{2}$ emissions are only slightly lower than in the reference settlement, but the emissions intensity is $20 \%$ lower. Both household groups have significantly lower environmental impacts than the Austrian average reflecting less car use and cleaner heating energy in Vienna.
\end{abstract}

C 2007 Elsevier B.V. All rights reserved.

\section{Introduction}

There is a growing interest in more sustainable lifestyles and urban forms. Sustainable consumption focuses on more benign consumption patterns and greener product choices (Fritsche, 2002; Hertwich, 2005b; Jackson, 2006; United Nations
General Assembly, 1992, 2002). Urban sustainability is interested in both the liveability of urban environments and in the effects cities have on resource consumption and pollution elsewhere (Alberti, 1996; Ravetz, 2000). These efforts presume that there are lifestyles and urban forms with various degrees of environmental impacts. There is a need to evaluate different

\footnotetext{
* Corresponding author.

E-mail addresses: michael.ornetzeder@oeaw.ac.at (M. Ornetzeder), edgar.hertwich@ntnu.no (E. Hertwich).

URL's: www.oeaw.ac.at/ita (M. Ornetzeder), www.ntnu.no/indecol (E. Hertwich).
} 
alternatives and understand their effect in detail, including trade-offs between alternatives and associated rebound or ripple effects (Hertwich, 2005a). A number of different assessment approaches and indicators have been proposed (Priemus, 2005). The tradition of household environmental impact assessment goes back to cumulative energy analysis (Bullard and Herendeen, 1975; Herendeen and Tanaka, 1976; Hertwich, 2005c; Stokes et al., 1994). Lenzen et al. (2004) have shown that this method can also provide interesting insights into urban sustainability.

This study investigates differences in the patterns of consumption between two settlements that are hypothesized to have different consumption patterns. One settlement has been advertised as 'car-free'; the tenants are contractually bound to not own a car and instead have the option to participate in a car-sharing scheme. The other settlement, in close proximity and of similar age as the first, is also a theme-settlement with the title 'women's workshop'. A shared interest and perspective among the tenants hence characterizes both settlements.

Car-free housing is often named as an example for sustainable consumption. With its shared facilities, such as workshops, laundry room, activity rooms, and playgrounds, the housing project in Vienna has a good infrastructure for sustainable consumption (Briceno and Stagl, 2006; Mont, 2004). Car-free housing projects are seen as a way of getting away from frequent car use and developing more liveable, pedestrian cities with more public recreational space (GlotzRichter, 1995; Scheurer, 2001). They are part of a larger movement promoting pedestrian zones, home zones (Barrell and Whitehouse, 2004), car-sharing (Cervero, 2003; Loose et al., 2006; Prettenthaler and Steininger, 1999), and shifting the urban transportation mix towards more sustainable modes of transport (Wright and Curtis, 2005; Zacharias, 2003). Car-free housing projects have not yet been subject to academic study, except for the overview by Scheurer (2001) and the documentation of the implementation of a project in the German city of Freiburg (Fritsche, 2002; Nobis, 2003). Most car-free housing projects examined by Scheurer comprise a few dozen to hundreds of flats, sufficient to provide some local infrastructure, but insufficient to influence traffic density and travel patterns in the entire neighbourhood. Tenants of these housing projects voluntarily subscribe to public transport and giving up their cars. Preisendörfer (2001) investigated households not owning a car in Germany and found that most of those households had below average income, which suggests that the carlessness might have to do with affordability. This is not the case for the households in our samples.

Car ownership influences how people organize their lives, both daily life routines such as how to do shopping, where and how to bring kids to various places, how to get to work; and where and when to engage in leisure activities. It was expected that the car-free housing project also attracted more environmentally conscious tenants, since it was advertised as 'car-free' and as having green features such as roof-top gardens, ponds ('biotopes'), and solar hot water collectors. The research question is whether there is a measurable difference in environmental impacts between households owning a car and those that do not own a car. Do they have systematically different consumption patterns, and - if so - how large is the difference in environmental impacts? How can this difference be explained?
To answer these questions, household environmental impact (HEI) can be calculated. HEI takes into account pressures onto the environment produced by the households directly, e.g. through combusting gasoline or a heating fuel, and those 'indirect' pressures that are connected to the production of products and services consumed by the household and the disposal of household wastes (Hertwich, 2005c; Tukker and Jansen, 2006). The approach used in these studies is based on combining household expenditure data with emissions intensities of household purchases as estimated by input-output analysis and life-cycle assessment. It has the merit of providing an overview over the entire household environmental profile, including production and disposal processes. Historically, this approach has focused on energy use and later greenhouse gas emissions, and only few studies attempt to cover a whole set of life-cycle impact assessment indicators (Nijdam et al., 2005). We first included those emissions that are included in the Austrian environmental accounts: $\mathrm{CO}_{2}, \mathrm{NO}_{x}, \mathrm{AOX}, \mathrm{COD}$, energy and hazardous waste. Due to the poor data quality for a number of these indicators, we focus this paper mostly on $\mathrm{CO}_{2}$ emissions. Most studies of household environmental impact reviewed by Hertwich (2005c) focus on average households either on a national or regional level. A number of studies investigate the correlation of HEI with income and other explanatory variables (Lenzen et al., 2006) or decompose the changes over time (Munksgaard et al., 2000).

In theory, household environmental impact assessment should be well suited to compare different groups of households and to quantify the environmental benefits brought about by environmental projects and policies. Policies often focus on a specific aspect, such as energy or car use, but only an evaluation based on the entire consumption basket is able to take into account direct and some indirect rebound effects (Hertwich, 2005a). The use of household impact assessment for the evaluation of specific projects, policy measures or experiments, however, is still in its infancy. It requires a combination of methods from the social sciences and environmental systems analysis. The only project-related study we are aware of that uses such methods is related to the work in Freiburg (Brohmann et al., 2002; Fritsche, 2002). That work has mainly emphasized guiding the development of a housing project and evaluates the environmental benefits of this project only vis-à-vis a hypothetical reference settlement rather than an actual control group.

\section{Research design}

Our aim was to understand the total environmental impacts of households. It was hence important to distinguish activities which cause a high impact per unit expenditure from activities that cause an average or a low impact per unit expenditure. The emissions intensities for $\mathrm{CO}_{2}$, for example, vary between 5 and $0.05 \mathrm{~kg} / €$, with the average at $0.45 \mathrm{~kg} / €$ (Haas et al., 2005). The distribution of emissions intensities is skewed, with a few expenditure categories accounting for most of the environmental impacts. Many studies have shown that transportation by cars and airplanes, household energy, and food are by far the most important contributors to the overall household environmental impact, with energy, planes and cars having the highest emissions intensities (Hertwich, 
2005c; Tukker and Jansen, 2006). For the total environmental impact, it makes little difference whether the household spends disposable income on furniture $(0.20 \mathrm{~kg} \mathrm{CO} / €)$, textiles $(0.20 \mathrm{~kg} / €)$, watches $(0.17 \mathrm{~kg} / €)$, or health and social work $(0.16 \mathrm{~kg} / €)$. We hence did not try to distinguish such expenditures. It should be noted that rail bound transport has emissions intensities $(0.2 \mathrm{~kg} / €$ for trains and 0.3 for the subway and tram system) similar to those of manufactured goods. From an environmental perspective it hence makes no difference whether individuals spend their money on train trips or, say, on furniture.

The study was also designed to capture key socio-economic characteristics of households, their environmental motivation, and household environmental impacts (HEI) (Haas et al., 2005). A standardized questionnaire as well as qualitative interviews were used to elicit motivational and social influences that might explain differences between consumption patterns in the studies settlements. The research was conducted in the following phases:

1. Analysis of the household environmental impacts of the average Austrian household, based on expenditure data from the national accounts (Kolleritsch, 2004), supplemented by data from the 2000 Consumer Expenditure Survey (CES)(Klotz, 2002). Selection of expenditure categories and variables which are important for the overall HEI and hence to be collected from the households in stage 2 .

2. A quantitative survey eliciting overall expenditure and consumption of environmentally significant goods by households in the two settlements, plus supplementary interviews, e.g. with the building management.

3. Calculation of the HEI for each household in the samples. Comparison of the settlements and their impacts.

4. Qualitative interviews with selected households to investigate motivations for different types of behaviour relevant to variations in HEI.

The challenging part of implementing this research design was to collect data sufficient in quantity and quality to allow a representative analysis of the residents of each building. Evaluations of HEI are often based on consumer expenditure surveys (CES) collected by statistical offices. These detailed surveys require that respondents record all their expenditures over a 2-4 week period followed by an extensive interview about larger purchases such as cars and holidays. Records from a single household are not seen as representative for that household, but only for the period that was recorded, so that artificial households are assembled from different records covering an entire year (Malinvaud, 1980; Aasness et al., 1993). Since the data quality of the consumption data in the inputoutput analysis is better than that in the CES (Kronsteiner-Mann and Schachl, 2006), that data was preferred for phase 1 and for the Austrian average, unless the detail of the CES was required.

A detailed assessment of consumer expenditure as it is contained in the CES was not possible within this study. We doubt that it would be possible to find a sufficient number of participants in the respective settlements. We therefore developed an approach for estimating the household environmental impact based on data obtained in a one-hour interview with the household, including getting access to utility bills. This approach and the corresponding survey make systematic use of existing data, such as building characteristics. The survey systematically covers households' ownership of other buildings and apartments, appliances, and cars, including associated energy use and transportation. In addition, expenditure for food and hotels and restaurants are recorded. The composition of residual expenditures not covered in our survey (i.e., the less important in terms of HEI) was assumed to be similar to the categories in the household demand vector of the input-output table. The survey is documented in Haas et al. (2005).

The survey of the car-free housing project was conducted in the summer of 2004. In total, 42 households of 244 in the settlement were surveyed. It was much more difficult to find individuals who were willing to respond to the survey than we had anticipated. Given this experience, the survey was slightly simplified for the reference settlement, in which 46 households of 357 were surveyed.

Our objective was to study the environmental aspects of living in a car-free settlement and to understand the environmentally significant effects on other consumption items (rebound effects) of such a lifestyle choice. We also wanted to understand some of the social aspects and mechanisms of living in such a settlement. The novelty of this research lies in applying techniques of household environmental impact assessments to studying an individual case of sustainable consumption (Hertwich, 2005c). We did not attempt to draw a causal connection between moving to the car-free settlement and reduced environmental impact. Making such a causal claim would require a longitudinal survey, which is more expensive to carry out. Nevertheless, through our questionnaire we do try to get some indication of how people have changed their behaviour since moving to the car-free settlement. Neither did we attempt to study the travel behaviour of the residents in great detail; that is, what means of transportation were used by whom, when and for what purpose. Such a study would require a diary-based approach and could not rely on a survey alone. While such a detailed travel survey would provide significant insights, it was not our aim to study transportation in such a detail. Rather, it was to identify differences in the household environmental profiles based on the main consumption items (including transport) with regards to emission intensities between the car-free settlement and a control group.

\section{The two settlements in comparison}

Both samples show a similar socio-economic structure, as Table 1 indicates. The households are of similar size, the available living space is of similar dimension, and the level of education of respondents in both settlements is far above the Viennese average. Because both settlements are relatively new and located in the same district of Vienna, it is not astonishing that the selected settlements are inhabited by people with similar socio-economic and cultural backgrounds. We observe rather homogenous social milieus.

In both settlements - in the car-free and the reference project - the average size of households is above the Viennese average (Table 1). Although large housing projects at the 
periphery typically attract young families, this is only partly true for our cases. In the car-free settlement, as well as in the reference project, nearly every second household is childless. Every fourth household in the car-free project is a single household. Just as many households are inhabited by only two persons. All in all it seems that there are slightly more large families and in total more children in the reference settlement than in the car-free project. Nevertheless, there are fewer singles and more families with children than the Viennese average.

Respondents in both samples are better educated than the Viennese population. Especially in the car-free settlement a high percentage of the inhabitants has a university degree. The concept of the project - to organize mobility without private car - was obviously attractive for persons with a high formal qualification. According to their level of education people in both settlements are working predominantly in white-collar jobs. Males could often be found in trendsetting industries like in IT or higher education. Many of the female occupants work as school teachers, as office workers, or in the health care system.

Given the high percentage of well educated people in both samples it is notable that the average family income in the selected settlements is not much above the Viennese average. In relation to the number of persons per household it is clearly below the average. Interesting is also the fact that both samples

Table 1-Average household characteristics in the two samples and Vienna at large

Car-free Reference Vienna project settlement

\begin{tabular}{|c|c|c|c|}
\hline $\begin{array}{l}\text { Average number of } \\
\text { people per household }\end{array}$ & 2.57 & 2.76 & 1.96 \\
\hline $\begin{array}{l}\text { Average number of } \\
\text { children per household } \\
\text { Occupation of } \\
\text { respondents }\end{array}$ & 0.67 & 0.91 & 0.55 \\
\hline White-collar worker & $52.4 \%$ & $52.2 \%$ & $25.3 \%$ \\
\hline Blue-collar worker & $8.7 \%$ & $2.5 \%$ & $13.3 \%$ \\
\hline Civil servant & $14.3 \%$ & $6.5 \%$ & $13.0 \%$ \\
\hline Self-employed & $2.4 \%$ & $4.3 \%$ & $5.7 \%$ \\
\hline Retired & $11.9 \%$ & $6.5 \%$ & $28.8 \%$ \\
\hline In-training & $7.1 \%$ & $8.7 \%$ & $8.5 \%$ \\
\hline Unemployed & $4.8 \%$ & $4.3 \%$ & $5.6 \%$ \\
\hline \multicolumn{4}{|l|}{ Education } \\
\hline Secondary school & $7.2 \%$ & $8.7 \%$ & $33.2 \%$ \\
\hline Vocational school & $4.8 \%$ & $15.2 \%$ & $28.6 \%$ \\
\hline Technical school & $4.8 \%$ & $10.9 \%$ & $10.6 \%$ \\
\hline A-levels & $38.1 \%$ & $39.1 \%$ & $15.8 \%$ \\
\hline University degree & $45.2 \%$ & $23.9 \%$ & $11.8 \%$ \\
\hline $\begin{array}{l}\text { Average annual net } \\
\text { income (Euro) }\end{array}$ & 32282 & 30867 & 28320 \\
\hline Minimum (Euro) & 9100 & 7000 & \\
\hline Maximum (Euro) & 72800 & 75000 & \\
\hline $\begin{array}{l}\text { Average annual net } \\
\text { income per capita (Euro) }\end{array}$ & 12560 & 11180 & 19720 \\
\hline Average size of flat $\left(\mathrm{m}^{2}\right)$ & 86.00 & 82.60 & 70.90 \\
\hline $\begin{array}{l}\text { Average size per person } \\
\left(\mathrm{m}^{2}\right)\end{array}$ & 33.50 & 30.00 & 36.20 \\
\hline Minimum $\left(\mathrm{m}^{2}\right)$ & 50 & 47 & \\
\hline Maximum $\left(\mathrm{m}^{2}\right)$ & 130 & 107 & \\
\hline
\end{tabular}

Table 2 - Selected information on transport

\begin{tabular}{lrr} 
Selected types of transport & $\begin{array}{r}\text { Car-free } \\
\text { project }\end{array}$ & $\begin{array}{r}\text { Reference } \\
\text { settlement }\end{array}$ \\
\hline $\begin{array}{l}\text { Bicycle use - more than } \\
\text { 200 days in 2003 }\end{array}$ & $36 \%$ & $9 \%$ \\
$\begin{array}{l}\text { Public transit - annual pass } \\
\text { (fraction of individuals) }\end{array}$ & $48 \%$ & $24 \%$ \\
$\quad \begin{array}{lr}\text { Austrian railways - discount card } \\
\text { Car }\end{array}$ & $47 \%$ & $10 \%$ \\
$\quad$ Households with 0 km in 2003 & $55 \%$ & $30 \%$ \\
$\quad$ Fraction of km with car-sharing/ & $49 \%$ & $0.8 \%$ \\
rental & & \\
$\begin{array}{l}\text { Airplane; households with no flights } \\
\text { in 2003 }\end{array}$ & $48 \%$ & $52 \%$ \\
$\begin{array}{l}\text { Average distance per household in } \\
\text { 2003 (km) }\end{array}$ & & \\
$\quad$ By car & & \\
$\quad$ By train, bus, ship (excluding & 700 & 10979 \\
commuting) & 6674 & 1489 \\
$\quad$ By airplane & & \\
Sum & 6686 & 6237 \\
\end{tabular}

The distances do not include commuting by public transport, walking and biking, as the distances for these modes of transport have not been determined.

contain high and low-income households; families with very different financial resources are living next to each other.

The size of the flats ranges between 50 and $130 \mathrm{~m}^{2}$. The average size in the car-free project is $86 \mathrm{~m}^{2}$, compared to $82.6 \mathrm{~m}^{2}$ in the reference project. Flats are larger compared to the Viennese average $\left(70 \mathrm{~m}^{2}\right)$, but per capita the living space is below average. In the car-free settlement the average living space is $33.5 \mathrm{~m}^{2}$ per person, compared to $30 \mathrm{~m}^{2}$ in the reference settlement. In other words the average 'consumption' of living space in the reference project is $10 \%$ below the car-free settlement and even $20 \%$ below the Viennese average.

Equipment ownership is slightly higher in the reference settlement, except for TV-sets. There are only a few clothdryers $(9.5 \%$ in the car-free project vs. $6.5 \%$ in the reference settlement). Most households own one or more computers, and about $75 \%$ have a connection to the internet. In the carfree settlement, only one of the 42 households owns a car, ${ }^{1}$ whereas in the reference settlement, $67 \%$ of the households own a car, $11 \%$ even more than one; in comparison, about $81 \%$ of the households in Vienna own a car (MA5, 2006). In both settlements almost everybody owns a bike.

As expected the results for mobility show significant differences between the two settlements (see Table 2 for selected results). Car-free households use public transport, whereas for the reference-households the car is the most important means of transportation. Car-free households have slightly more air trips and longer distances than the reference group, although the difference is not large. The overall mileage of the average car-free household - covered by car, train, bus, ship and airplane - was clearly below the reference group. While car-free households have travelled an average distance of about

${ }^{1}$ This is in violation with the contract, but the householder argues that he needs it for his job. 
$14,000 \mathrm{~km}$, reference households travelled almost 19,000 km. Note, however, that these distances do not include commuting on the local public transportation system, biking or walking.

In the car-free settlement cars play indeed a very limited role to meet private transport needs - therefore residents match the aim and label of the project rather well. In 2003, more than half of the car-free households did not use a car at all (Table 2). The one household owning a car is responsible for more than $60 \%$ of total car mileage in the car-free settlement sample. The remaining mileage was covered by car-sharing, rental or borrowed cars. According to our respondents the most important reason to use a car is to do purchases of bulky items. The situation is quite different in the reference project. Most of these households own at least one private car which is the main means of mobility of the family. On average each household in the reference settlement drives $11,000 \mathrm{~km}$ per year. The reference value in the car-free settlement is $700 \mathrm{~km}$.

\section{Household environmental impact calculations}

Household environmental impact assessment has been pioneered in the field of energy analysis with the calculation of embodied and direct energy use by different household groups. The first analyses of this type by Herendeen and others (Bullard and Herendeen, 1975; Herendeen, 1978; Herendeen and Tanaka, 1976) already combined energy inputoutput analysis (IOA) to estimate the energy use for the products and services consumed by a household with data on the consumption of different energy carriers by the households themselves. Today, this type of analysis also takes into account emissions and potentially resource use and material flows. For a review of the literature, see Hertwich (2005c). The objective of this type of analysis is to quantify the contribution of different household activities or demand categories, such as food, clothing, transportation and dwellings, to the overall household environmental impact.

In this study, we started by analysing the environmental impact of the average Austrian household, using input-output tables for 2000 (Kolleritsch, 2004), the environmental accounts of 1999/2000 for air emissions and energy and of 1995 for AOX and COD (Eurostat, 2001), and data from the 1999/2000 consumer expenditure survey (Klotz, 2002). We found that transportation and energy use in households are the most important contributors to greenhouse gas emissions (Haas et al., 2005). Direct energy use and transportation are usually not or only incompletely represented in input-output analyses, so we decided to use direct emissions calculations and life-cycle assessment (LCA) data to model these impacts.

\subsection{Input-output analysis}

Emissions intensities of commodities in basic prices were calculated following the standard equation

$M=F(I-A)^{-1}$

Where A represents the input-output coefficients in commodity-commodity formulation calculated from make and use tables using the industry-technology assumption. The input-output coefficients include both domestic and imported products $A=A^{d}+A^{i}$ (Peters and Hertwich, 2004), where imports are treated as if they were produced domestically. The matrix $F$ depicts the emissions or resource use per unit commodity produced. ${ }^{2}$ Emissions and resource use per industry sector are allocated to commodities using the normalized make table, i.e. reflecting the industry-technology assumption. The problem with using the Austrian environmental accounts as sources for environmental pressures is that data exists for only a limited number of stressors $\left(\mathrm{CO}_{2}, \mathrm{NO}_{x}, \mathrm{COD}, \mathrm{AOX}\right.$, hazardous waste, energy). A comprehensive assessment of impact categories as used in LCA (Udo de Haes et al., 2002) is therefore not possible. The data for some of these categories is outdated and of poor quality, only the results for $\mathrm{CO}_{2}$ emissions are of better quality because they need to be reported to the UNFCCC.

The emissions intensities of different commodities in purchaser prices were calculated from those in basic prices using tables on trade and transport margins, taxes and subsidies for the different products. The tables include information on which sectors produce the different margins, so that the emissions connected to trade and transport are included in the emissions intensities of the commodities. The results indicate that there are many services and products which have similar emissions per unit expenditure. The emissions intensities vary between $0.05 \mathrm{~kg} \mathrm{CO}_{2} / €$ for education to $0.56 \mathrm{~kg} \mathrm{CO}_{2} / €$ for paper. Very few commodities show higher intensities. Some of these are not purchased by households directly, e.g. basic metals (1.5 kg CO$/ €)$. We decided not to try to determine the purchase of less important commodities with emissions intensities that are not far from the average commodity, because variations in the purchase of these commodities would not have a significant impact on the overall household environmental impact. Rather, we decided to focus on purchases that typically contribute considerably to the total. These are commodities with high emission intensities, such as energy and land transport (1.5 and $\left.1.7 \mathrm{CO}_{2} / €\right)$, and commodities which take up a significant part of the household budget (food, hotels and restaurants).

\subsection{Life-cycle analysis}

We use data from the Eco-Invent database (Frischknecht, 2004) for the Austrian electricity mix and for trains, coaches, and airplanes. For green electricity, we use the LCA numbers for a Swiss wind power plant. For car transport, all data is based on the LCA of a VW Golf A4 (Schweimer and Levin, 1999). Data relating to car production and maintenance was

\footnotetext{
${ }^{2}$ We had to produce our own A table because Statistics Austria provides an A table only for the commodity-technology assumption in commodity-commodity formulation while emissions data exists only on an industry basis. Manual manipulations are involved in producing the A table, and we could not reproduce this so that we were not able to allocate industry emissions to the commodities as represented by the A table. Different practices exist in HEI assessments. Lenzen (2001) also combines make and use table using the industry-technology assumption, while Peters and Hertwich (2006) use the A table provided by the Statistical office.
} 
Table 3 - Distribution of per capita household environmental impacts (HEI) in 2000 based on input-output calculations

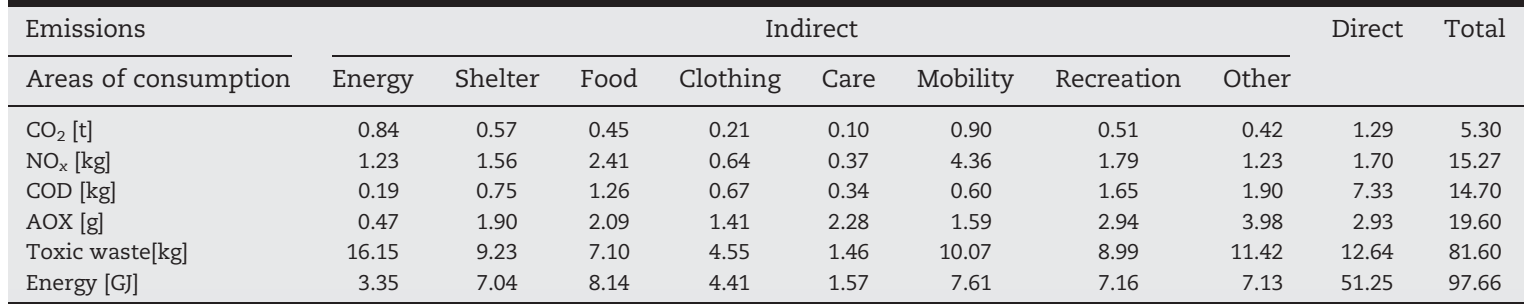

captured in a per-km component. This assumes that the production and maintenance of all cars causes about as much pollution as the Golf A4. The fuel-related and direct emissions were captured in a per-liter component. Road infrastructure was not considered. Emissions for district heating were obtained from the regional utility (Wallisch, 2004). We included only direct emissions, not emissions connected to building the infrastructure. Emissions from using the city's public transport system were calculated from the energy use of Vienna's transport system (Wiener Linien, 2004), passenger number, and appropriate emissions coefficients for buses fuelled with natural gas (Beer et al., 2000). Again, the life-cycle assessment was not complete as the infrastructure was not considered. The use of such incomplete assessments is not ideal but can justified by the finding that for energy using products, the energy use usually dominates in the LCA results (Hanssen, 1998).

\section{Comparison of impacts}

Table 3 presents the average per capita direct and indirect emissions in Austria as obtained from the input-output calculations. This assessment does not include direct emissions from transport, because the input-output tables do not specify the direct emissions for household transportation. The reported transportation could not be assigned to specific user groups based on this information. From the transportation survey, we estimated the average $\mathrm{CO}_{2}$ emissions to be $0.6 \mathrm{t} /$ person. The calculations assumed that all products and services consumed have been produced by using Austrian production technology, no matter whether they have been produced domestically or have been imported. This is likely to result in an underestimate of certain emissions, e.g. those connected to clothing and other consumer goods (Peters and Hertwich, 2006), but those emissions are not the focus of our study.

The comparison of the two settlements uses the inputoutput calculations only for part of the emissions, as described in the methods section. The evaluation of emissions of the two settlements in Table 4 indicates that in some categories, the car-free settlement has lower per capita environmental impacts, while in other categories the reference settlement is better. The difference is never more than $20 \%$. For all indicators, the average Austrian household has higher impacts, and it also has higher expenditures. Please note that the numbers for toxic waste generation and energy use are somewhat more uncertain than the other numbers. The data for primary energy use for the energy and transport categories was estimated. The assessment of toxic waste was based only on the IO table. Because of uncertainties in the emissions factors used in connection with the IOA and the data in the underlying LCA, the emissions estimates for $\mathrm{AOX}, \mathrm{COD}$, and $\mathrm{NO}_{x}$ are more uncertain than those for $\mathrm{CO}_{2}$, which can be calculated quite accurately from a carbon balance.

In the following analysis we will focus on $\mathrm{CO}_{2}$ emissions, because of the better data quality and because of the importance of global warming in the current public debate. Fig. 1 shows a comparison of the two settlements and the Austrian average using the categories we have distinguished in our calculations. Different types of transportation are specified: public transportation in Vienna, public transportation for recreation/trips/holidays (i.e. airplanes, trains, busses, ships), and use of cars, mopeds and motorcycles. The households in the car-free settlement have lower per capita $\mathrm{CO}_{2}$ emissions. Per Euro spent, the car-free settlement has $20 \%$ lower $\mathrm{CO}_{2}$ emissions than the reference settlement. Transportation's share of the household $\mathrm{CO}_{2}$ emissions is lower for the car-free settlement (35\%) than for the reference settlement $(44 \%)$ and the average Austrian household (42\%). In the car-free housing project, the emissions associated with energy are $25 \%$ lower than in the reference settlement, because there households use $30 \%$ less electricity and have more subscribers of green electricity, which causes only $10 \%$ of the emissions of the gridaverage. The energy-related emissions are much lower in the two Viennese settlements than in Austria on average, because of the use of district heating for heating and hot water. Since waste incineration, an important heat source in Vienna, is treated as 'carbon neutral,' the $\mathrm{CO}_{2}$ emissions are much lower than those from oil and natural gas, the most important heating fuels in other urban, suburban and rural areas.

The overall differences between the settlements in $\mathrm{CO}_{2}$ emissions and energy use are lower than the variations within

Table 4 - Comparison of annual per capita household environmental impact and expenditure between the two settlements and the average Austrian household

\begin{tabular}{lccccccc} 
& $\mathrm{CO}_{2}[\mathrm{t}]$ & $\mathrm{NO}_{\mathbf{x}}[\mathrm{kg}]$ & $\mathrm{COD}[\mathrm{kg}]$ & $\mathrm{AOX}[\mathrm{g}]$ & Toxic waste $[\mathrm{kg}]$ & Energy $[\mathrm{G}]$ & Expenditure $[\mathrm{k} €]$ \\
\hline Car-free & 4.2 & 14 & 10 & 15 & 61 & 75 & 12.7 \\
Reference & 4.5 & 13 & 9 & 13 & 54 & 80 & 11.2 \\
Average & 7.0 & 16 & 11 & 16 & 72 & 101 & 14.3 \\
\hline
\end{tabular}




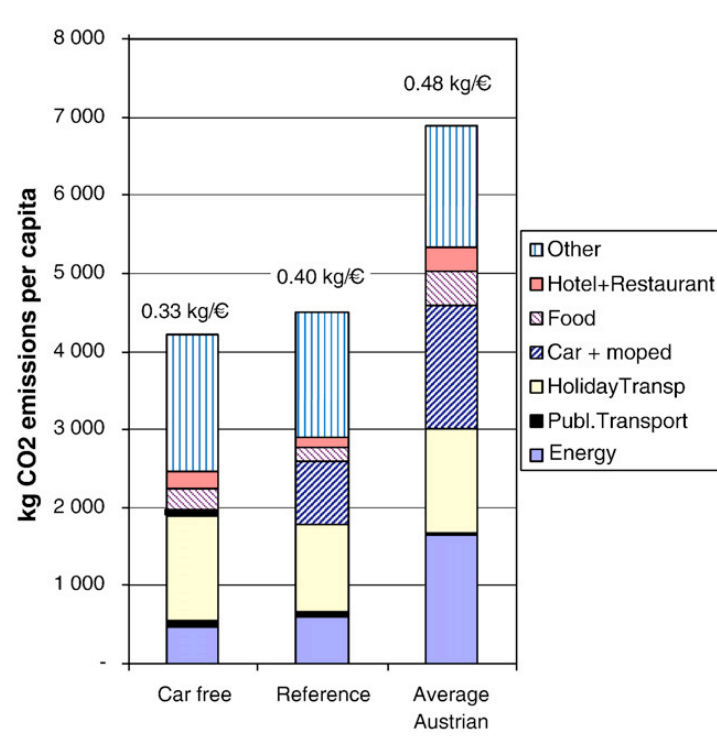

Fig. 1-Per capita $\mathrm{CO}_{2}$ emissions (in $\mathrm{kg} /$ capita) and average emission intensities (in $\mathrm{kg} /$ Euro) of the two settlements in comparison with the average Austrian.

the settlements. This may come as a surprise, but this result is not that difficult to explain:

- For the car-free settlement, 53\% of the emissions are caused by the categories food, hotels and restaurants, and 'other,' which are estimated using input-output analysis. To estimate the 'other' emissions, we used a typical expenditure pattern as derived from the consumer expenditure survey. Any systematic variation in these expenditures is not covered by our assessment. The car-free settlement has a slightly higher income, which results in a higher impact in the 'other' category ( $42 \%$ of total $\mathrm{CO}_{2}$ emissions, vs. $35 \%$ in the reference settlement). In the categories assessed by LCA, the reference settlement had $33 \%$ higher $\mathrm{CO}_{2}$ emissions per capita than the car-free settlement.

- The rebound effect is important (Hertwich, 2005a). It is assumed here that everybody spends all their income; any money saved by not owning a car goes to some other purpose. The 'other' category has only $14 \%$ of the emissions intensity of cars (Table 5). If the money saved by not owning a car is spent on air transport, much higher emissions can result. As far as we could determine, these households eat more out and have a higher consumption in the 'other' category.

- For the car-free settlement, air transport accounts for $64 \%$ of the $\mathrm{CO}_{2}$ emissions associated with energy and transport. For the reference settlement, this number is only $43 \%$. The per capita $\mathrm{CO}_{2}$ emissions of energy and transport not consider- ing air transport are $720 \mathrm{~kg}$ (16\% of total) in the car-free settlement and $1500 \mathrm{~kg}(36 \%)$ in the reference settlement. The car-free settlement also has a lower emissions intensity value for holiday transport including air transport, because of the use of trains and buses instead of the car.

Past investigations of energy use and of $\mathrm{CO}_{2}$ emission of households based on CES have shown that both variables are a strong function of income (Herendeen, 1978; Herendeen and Tanaka, 1976; Lenzen et al., 2006; Moll et al., 2005; Stokes et al., 1994; Vringer and Blok, 1995; Wier et al., 2001). Income elasticities of energy use are commonly between 0.6 and 0.9 (Hertwich, 2005c). This result may be, to a certain degree, a modelling artefact, because indirect energy use and emissions were mostly determined with IOA and therefore are systematically correlated with the expenditure level. In addition, environmental differences between, e.g. buying one luxury car or two inexpensive family cars at the same cost cannot be distinguished. Similarly, spending more money on buying organic food is modelled as resulting in higher impacts compared to buying the same products from conventional products. This problem of course also affects our study. Despite these shortcomings the investigation of the relationship between expenditure and $\mathrm{CO}_{2}$ emissions still provides some interesting insights.

Fig. 2a indicates that in our two samples, there is a fairly wide scatter of $\mathrm{CO}_{2}$ emissions especially for higher income. The situation changes when we subtract air transport, as Fig. $2 b$ shows. There is a high correlation between income and $\mathrm{CO}_{2}$ emissions for households across settlements that do not own a car. The income elasticities are similar, 0.88 and 0.82 , as the power-law fit in Fig. $2 b$ shows; that is, the car-free households in the reference settlement are very similar to the car-free settlement. For the car-owning tenants of the reference settlement, however, the correlation of emissions with income is much lower and the income elasticity is only 0.44. This is a very interesting result: the car establishes a 'necessity' with a 'stable' $\mathrm{CO}_{2}$ emission level relatively independent of income. It implies that once the car has been purchased, behaviour - that is, car use - becomes more important while the relative importance of income for household $\mathrm{CO}_{2}$ emissions decreases.

Looking at our whole sample, there is little correlation between income and air transport $\left(r^{2}=0.03\right)$ and no correlation between the $\mathrm{CO}_{2}$ emissions of ground transport and air travel. In our sample, there is hence no indication that the money saved from not owning a car is systematically diverted to air travel.

Table 5 indicates the $\mathrm{CO}_{2}$ intensity of the different consumption categories investigated. Most consumption categories contain emissions intensities either from several IO categories ('other') or from life-cycle assessment, and they are weighted results. The low emissions intensity for 'car and moped transport' for the car-free settlement, for example, results from the fact that car rental/sharing is more expensive per $\mathrm{km}$. It shows that many categories have a similar $\mathrm{CO}_{2}$ intensity.

Table $5-\mathrm{CO}_{2}$ emissions intensity in $\mathrm{kg} \mathrm{CO}_{2} / €$ for different expenditure categories

\begin{tabular}{lcccccccc} 
& Energy & Public transport & Holiday transport & Car moped & Food & Hotel restaurant & Other & Total average \\
\hline Car-free & 0.96 & 0.35 & 4.50 & 0.54 & 0.24 & 0.18 & 0.19 & 0.33 \\
Reference & 1.50 & 0.47 & 7.37 & 1.45 & 0.24 & 0.18 & 0.19 & 0.40 \\
Average & 3.08 & 0.40 & 6.52 & 1.49 & 0.24 & 0.18 & 0.19 & 0.49 \\
\hline
\end{tabular}



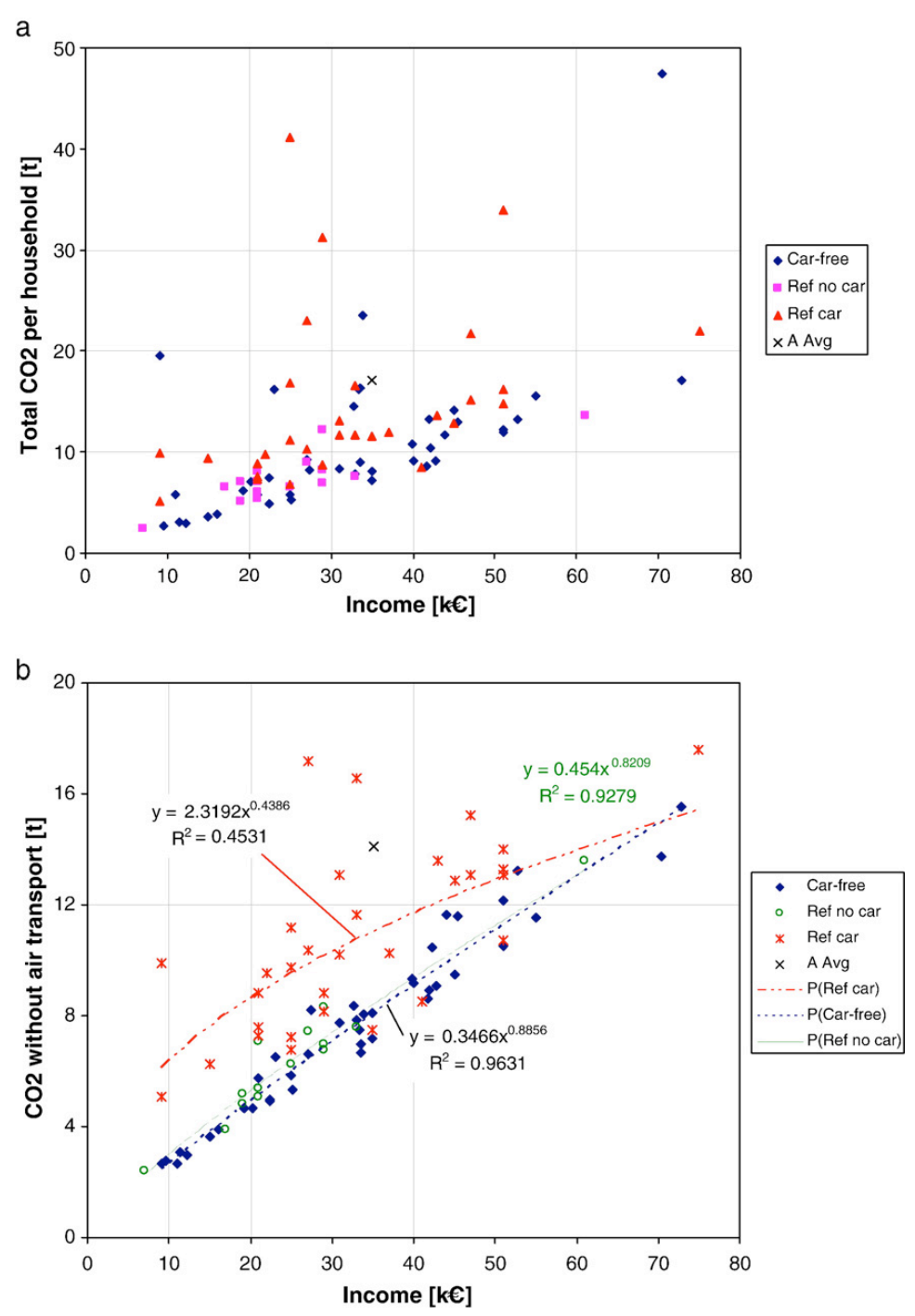

Fig. 2-Total $\mathrm{CO}_{2}$ emissions per household, (a) with and (b) without air transport, as a function of household income. For the reference settlement (ref), we distinguish between households with and without cars.

Only those with intensities significantly different from the average can cause substantial deviations from a linear relationship between expenditure and $\mathrm{CO}_{2}$ emissions. For our two samples, these are air transport, energy use, and car use. The physical design of the buildings (insulation, heating system, design) conditions much of the energy use, so that only car use and air planes contribute to a substantial difference among the samples. There seems to be no correlation between car use and income in the reference settlement.

\section{Social aspects of consumption choices}

The survey indicates that there are two distinct causes for the lower $\mathrm{CO}_{2}$ emissions in the car-free settlement: differences in the mobility patterns and the popularity of green electricity. Environmental effects of other ecological behaviour, such as recycling, the purchase of organic food and low-meat diets could not be determined in this study. We reasoned at the outset that both infrastructure aspects (e.g. bicycle parking and repair facilities) and social mechanisms that define 'normal' behaviour would be important for shaping the consumption patterns in the car-free settlement. We were interested in how the tenants perceived this settlement, how they interacted with their neighbours, what motivated the choice of moving to the settlement, and whether moving there resulted in a change of behaviour. In preparing for the survey, we conducted 5 interviews with building managers and the tenants' representatives. In the survey, there was a number of questions relating to motivations, neighbourly relationships, self-perception and 
Table 6 - The most important motivations to move to the settlement

\begin{tabular}{lcc}
$\begin{array}{l}\text { Five most important } \\
\text { motivations }\end{array}$ & $\begin{array}{c}\text { Car-free } \\
\text { project (\%) }\end{array}$ & $\begin{array}{c}\text { Reference } \\
\text { settlement (\%) }\end{array}$ \\
\hline $\begin{array}{l}\text { Recreation area 'Alte Donau' } \\
\text { Generous common areas and } \\
\text { facilities }\end{array}$ & 85 & 58 \\
To live in a 'green' and & 73 & 17 \\
healthy environment & & 61 \\
$\begin{array}{l}\text { Quiet site/no noise pollution } \\
\text { Bright, sunny apartment }\end{array}$ & 71 & 61 \\
Need for more living space & 68 & 54 \\
Good floor plan & 44 & 63 \\
\hline For a full list, see Haas et al. (2005). & 46 & 61 \\
\hline
\end{tabular}

perception of others, and ecological motivation. After the survey, we conducted four in-depth interviews in the car-free settlement with residents representing typical styles of consumption.

\subsection{The role of infrastructure}

We asked tenants to list the five most important motivations for moving to the settlement. Our survey follows a postoccupancy survey which was conducted 18 months after the car-free settlement was opened (Gutmann and Havel, 2000). The results in Table 6 indicate that for the car-free project, the proximity to the recreation area 'Alte Donau', the shared facilities and the quality of the surroundings are the most important motivating factors. The car-free feature was less important. Only 10 out of 42 respondents have mentioned the car-free feature as relevant for their decision. These results are similar to those obtained in the post-occupancy survey (Gutmann and Havel, 2000). For the reference settlement more reasons for moving into the settlement were named. There was a larger share of people who needed to move, but the attributes of the apartments and surroundings were also important.

The car-free feature and the ecological aspects were decisive for only a minority of tenants who moved to the settlement. According to the post-occupancy survey, only $50 \%$ of the male and $30 \%$ occupants have owned a car at any time of their life (Gutmann and Havel, 2000). We do not know the shares for the reference settlement but it is important to note that the mobility patterns of the tenants of the car-free

\section{Table 7 - Ecological awareness in the settlement}

\begin{tabular}{lcc} 
Statements & $\begin{array}{c}\text { Car-free } \\
\text { project (\%) }\end{array}$ & $\begin{array}{c}\text { Reference } \\
\text { settlement (\%) }\end{array}$ \\
\cline { 2 - 3 } & Very and fairly true \\
\hline $\begin{array}{l}\text { In this settlement we have much } \\
\text { more ecofriendly people than in } \\
\text { similar settlements }\end{array}$ & 92 & 27 \\
$\begin{array}{l}\text { Waste separation is very } \\
\text { important in this settlement }\end{array}$ & 44 & 20 \\
$\begin{array}{l}\text { Green consumption is an } \\
\text { important topic of conversation in } \\
\text { this settlement }\end{array}$ & 34 & 2 \\
\hline
\end{tabular}

Table 8 - Social control regarding ecological behaviour

\begin{tabular}{|c|c|c|}
\hline \multirow[t]{2}{*}{ Statements } & $\begin{array}{c}\text { Car-free } \\
\text { project (\%) }\end{array}$ & $\begin{array}{c}\text { Reference } \\
\text { settlement (\%) }\end{array}$ \\
\hline & \multicolumn{2}{|c|}{ Very and fairly true } \\
\hline $\begin{array}{l}\text { Everybody knows everything } \\
\text { about other people in the } \\
\text { settlement }\end{array}$ & 24 & 19 \\
\hline $\begin{array}{l}\text { Sometimes I observe that } \\
\text { neighbours do not separate their } \\
\text { waste }\end{array}$ & 26 & 11 \\
\hline $\begin{array}{l}\text { If somebody from the settlement } \\
\text { buys a new car, everybody will } \\
\text { know it }\end{array}$ & 49 & 5 \\
\hline
\end{tabular}

settlement are significantly different from those of the reference settlement:

- According to our results it is clear that bicycles are a major means of transportation in the car-free settlement; and the existing facilities support this mode of transport to a certain extent. Easy access to and space for bikes were already important topics during the planning process of the buildings. Future tenants argued for additional bicycle sheds - against the landscape planner's initial concept - and succeeded. Although households in both settlements are quite well equipped with bicycles (with approximately one bike per person), the use patterns differ significantly. While in the car-free project $36 \%$ of all respondents have used their bicycle on more than 200 days in the year 2003, only $9 \%$ showed the same extensive bike use in the reference settlement. ${ }^{3}$ Despite this large difference it is difficult to assess the role of the bike-friendly facilities. Those conditions are important, but perhaps only a part of the overall setting. It seems that many people, when they move to the carfree settlement, change their mobility habits. For example, $41 \%$ of the respondents say that they have started to use their bicycle much more often than before (reference settlement: $22 \%$ ).

- We know from some of the qualitative expert interviews that car-sharing in the car-free project was less 'successful' than the car-sharing company had expected. They started with five cars, but due to little interest the company had to reduce the number to three. The results from our survey could also be interpreted in this way. Only $41 \%$ of all respondents have used car-sharing during the studied period, the year 2003, and covered an average distance of about $600 \mathrm{~km}$. In comparison only $7 \%$ of households in the reference settlement (without car-sharing facility) have used car-sharing in 2003. Although it is very easy to rent a car in the

${ }^{3}$ These results were obtained by interviews and are hence based on recollection. The travel survey literature indicates that recollection-based estimates are less reliable than estimates from travel dairies. The difference between the two samples is so large, however, that we are confident that it is real.

${ }^{4}$ In one of the interviews this change is described in the following words:'...it is because of this settlement that I am living again in a bicycle-friendly environment. When I came here, I bought a new bike, and I use it a lot. I was used to do things this way many years ago, than I had no bike for about 10 years. Since I moved here, I have been using my bike for many different trips' (interview 1). 


\section{Table 9 - Identification with the settlement}

\begin{tabular}{lcc} 
Statements & $\begin{array}{c}\text { Car-free } \\
\text { project (\%) }\end{array}$ & $\begin{array}{c}\text { Reference } \\
\text { settlement (\%) }\end{array}$ \\
\cline { 2 - 3 } & Very and fairly true \\
\hline $\begin{array}{l}\text { Many tenants are proud to live in } \\
\text { our settlement } \\
\begin{array}{l}\text { Compared to other new } \\
\text { settlements in the neighbourhood } \\
\text { our settlement is very special }\end{array}\end{array}$ & 82 & 29 \\
\hline
\end{tabular}

car-free settlement, tenants use this offer quite hesitantly. Most car-free households cover their mobility needs by means of public transport and bicycle. On average, car-free households travel 10 times as far by train as by car and bus. In contrast, train transport covers only $13 \%$ of the distance of car transport for respondents in the reference settlement.

\subsection{Attitudes and perceptions}

A number of questions in the survey addressed both the importance of environmentally friendly consumer behaviour and of attitudes and perceptions. Most of the respondents think that there are much more eco-friendly people in the car-free settlement than in similar settlements in Vienna. In contrast only a minority in the reference settlement feels confident with this statement. Differences between the two settlements with regards to behaviour are also indicated by the importance of waste separation and green consumption as a topic of daily conversations in the car-free settlement. One third of all respondents in the car-free settlement think that green consumption is a relevant and frequent topic. In the reference settlement only one of all (46) interviewed persons shares that opinion. There is a clear difference in the perception of the general ecological awareness between the settlements. Ecological awareness plays a more important role as part of the social norms. It can be expected to act as reinforcing certain behaviours in the carfree settlement than in the reference settlement (Table 7).

\subsection{Social cohesion and social control}

Another important element of the social conditions within groups and more specifically within a settlement is social control. For our problem it was important to measure forms of social control regarding the ecologically relevant behaviour. Here the relevant question is as follows: To what extent do tenants recognize how other people in the settlement live? We have used several items to measure this question. In all cases the results show clear differences between the two settlements. In the carfree settlement the share of well informed tenants is much higher than in the reference group. It seems, however, that with the exception of car non-use, social control is not a big issue. Half of the respondents believe that it would not be possible for tenants to buy a car without everybody knowing it (Table 8).

Although both case settlements have been developed around a specific theme, car-free living versus for women-designed housing, the identification with the settlement seems to be much higher in the car-free project. Eight of ten respondents in the car-free settlement think that 'many tenants are proud to live especially in the car-free settlement'. In comparison, in the
Table 10-Social cohesion in the settlement

\begin{tabular}{lcc}
\hline Statements & $\begin{array}{c}\text { Car-free } \\
\text { project (\%) }\end{array}$ & $\begin{array}{c}\text { Reference } \\
\text { settlement (\%) }\end{array}$ \\
\cline { 2 - 3 } & \multicolumn{2}{c}{ Very and fairly true } \\
\hline $\begin{array}{l}\text { The solidarity within the } \\
\text { settlement is very strong }\end{array}$ & 87 & 24 \\
$\begin{array}{l}\text { There are good neighbourly } \\
\text { relationships in this settlement } \\
\begin{array}{l}\text { To help each other is very } \\
\text { common in this settlement }\end{array}\end{array}$ & 85 & 18 \\
\hline
\end{tabular}

reference settlement only three out of ten respondents think that this view is shared by their neighbours. This is further exemplified by the statements presented in Table 9 .

With regards to social cohesion the comparison between the two settlements shows significant differences as well: While most of the respondents in the car-free settlement are convinced that social cohesion is very strong in their neighbourhood, in the reference settlement only a minority believes this to be true. Similarly, more than eight of ten carfree tenants think that 'the solidarity within the settlement is very strong', that 'there is a good neighbourly atmosphere' and that it is 'very common to help each other'. Only this last point regarding the helpfulness in the settlement seems to be of some relevance in the reference settlement as well (Table 10) .

We know from some of the qualitative interviews that there is a very active community in the car-free settlement. Every year there are some self-organised festivities and flea markets in the courtyard. Moreover, most of the common facilities in the car-free settlement are managed by some residents themselves. Therefore it is not surprising that all respondents (100\%) in the car-free settlement say that there are 'many joint activities for all residents.' In the reference settlement only one out of ten subscribes to this statement. In general, residents in the car-free settlement maintain much more social contacts with neighbours in their settlement. On average respondents in the car-free settlement estimate that they have 16 friends in the settlement and know more than 100 by sight, compared to 7 friends and 62 known neighbours in the reference settlement. In the car-free settlement it is also more likely that people did know some residents before they moved in (Table 11) .

\subsection{Information flow}

Finally, there are also clear differences between the two settlements regarding the possibilities and ease to get

Table 11 - Social contacts within the settlement

\begin{tabular}{|c|c|c|}
\hline \multirow[t]{2}{*}{ Questions } & $\begin{array}{l}\text { Car-free } \\
\text { project }\end{array}$ & $\begin{array}{l}\text { Reference } \\
\text { settlement }\end{array}$ \\
\hline & \multicolumn{2}{|c|}{$\begin{array}{l}\text { Number of people } \\
\text { (average) }\end{array}$} \\
\hline $\begin{array}{l}\text { How many people in the settlement } \\
\text { would you call 'friends'? }\end{array}$ & 16 & 7 \\
\hline $\begin{array}{l}\text { How many people did you already know } \\
\text { before you moved to this settlement? }\end{array}$ & 2.7 & 0.2 \\
\hline $\begin{array}{l}\text { How many residents do you know by } \\
\text { sight? }\end{array}$ & 101 & 62 \\
\hline
\end{tabular}


Table 12 -Information about environmentally friendly consumption in the settlement

\begin{tabular}{lcc} 
Statements & $\begin{array}{c}\text { Car-free } \\
\text { project } \\
(\%)\end{array}$ & $\begin{array}{c}\text { Reference } \\
\text { settlement (\%) }\end{array}$ \\
\cline { 2 - 3 } & Very and fairly true \\
\hline $\begin{array}{l}\text { It's easy to get information on } \\
\text { environmentally friendly } \\
\text { consumption in the settlement }\end{array}$ & 87 & 0 \\
$\begin{array}{l}\text { Environmentally friendly } \\
\text { consumption is an important topic } \\
\text { of conversation in the settlement } \\
\begin{array}{l}\text { Environmental topics are often on } \\
\text { the agenda in conversations with } \\
\text { my neighbours }\end{array}\end{array}$ & 29 & 2 \\
\hline
\end{tabular}

information on ecological issues. Respondents in the car-free settlement are more or less in complete agreement that it is easy to get information on ecological consumption in the settlement. Most of this information is provided by residents which are active in various initiatives (outside the settlement). Most residents are registered on the internal mailing list that works as an effective means to spread information to most of the neighbours. One third of the respondents in the car-free settlement think that environmentally friendly consumption is an important topic of conversation. After all, three out of ten respondents stated that environmental topics are often on the agenda in conversations with neighbours. The situation in the reference settlement is completely different. The neighbourhood is not seen as a source of environmentally relevant information at all (Table 12).

Table 13 - Correlations between settlement attributes, $\mathrm{CO}_{2}$ per capita, air travel, and car travel

\begin{tabular}{|c|c|c|c|}
\hline \multirow[t]{2}{*}{$\begin{array}{l}\text { Settlement } \\
\text { attributes }\end{array}$} & $\mathrm{CO}_{2}$ per capita $(\mathrm{t})$ & $\begin{array}{l}\text { Air travel } \\
(\mathrm{km})\end{array}$ & $\begin{array}{l}\text { Car travel } \\
(\mathrm{km})\end{array}$ \\
\hline & \multicolumn{3}{|c|}{ Kendall-Tau-b ${ }^{a}$} \\
\hline $\begin{array}{l}\text { Environmental } \\
\text { awareness }\end{array}$ & -.052 & -.150 & $\left..305^{* *}\right)^{\mathrm{b}}$ \\
\hline Social control & .135 & .022 & $.180\left(^{*}\right)$ \\
\hline Identity & -.022 & -.069 & .129 \\
\hline Cohesion & $.177\left(^{*}\right)$ & -.006 & .159 \\
\hline Social contacts & $.207\left(^{* *}\right)$ & .006 & $.258\left(^{* *}\right)$ \\
\hline Information & .039 & -.105 & $.339\left(^{* *}\right)$ \\
\hline \multicolumn{4}{|c|}{$\begin{array}{l}\text { ** Correlation is significant at the } 0.01 \text { level ( } 2 \text {-tailed). } \\
\text { "Correlation is significant at the } 0.05 \text { level (2-tailed). } \\
\text { a Kendall-Tau-b is a correlation coefficient that works well with } \\
\text { ordinal levels of measurements (this is the case with the perceived } \\
\text { social conditions). It does not need a normal distribution and its fits } \\
\text { with small samples. In our case it measures the "strength of } \\
\text { relationship" between perceived social conditions in the settlement } \\
\text { (and other subjective items) and ecological behavior (air travel in km } \\
\text { and car travel in km). The value of Kendall-Tau-b lies between- } 1 \text { and } \\
\text { 1. The value } 1 \text { means that the agreement between the two rankings is } \\
\text { perfect. If the rankings are independent, the coefficient has value } 0 \text {. } \\
\text { b Please note that the questions were phrased in a way that a lower } \\
\text { value for the variable "environmental awareness" corresponds to a } \\
\text { higher level of actual awareness. The positive sign indicates that } \\
\text { the higher the awareness (i.e., the lower the value) the fewer } \\
\text { kilometers had been traveled by car. }\end{array}$} \\
\hline
\end{tabular}

6.5. Relationship between social factors and environmental impacts

The respondents describe their settlements in very different terms. The car-free settlement seems to be a kind of small village within the city: a village where people know each other, a place with a colourful social life and with plenty ecologically aware residents. In contrast to that description the reference settlement seems to be more typical for Vienna: It is a nice place to live but the neighbourhood is not dominant in any way. One can enjoy urban anonymity, if desired. But is there an empirical relationship between those diverse social conditions in the settlements and the environmental impacts of households? Table 13 indicates that there is in fact a correlation between the perception of the 'social life' in the settlement and the environmental impact; even if it is not the overall $\mathrm{CO}_{2}$ emission which could be explained by settlement attributes. There is a notable statistical relationship (indicated through a significance level of at least 0.05 ) between environmental awareness, social control in the neighbourhood, social contacts in the settlement, and the availability of ecological relevant information in the settlement and the car mileage per year. On the other hand, there is absolutely no correlation between those items and air travel.

The high empirical variance of $\mathrm{CO}_{2}$ emissions per capita in both samples is mainly a function of air travel (Pearsons

Table 14 - Correlations between individual attributes, $\mathrm{CO}_{2}$ per capita, air travel, and car travel capita $(\mathrm{t})$ travel travel $(\mathrm{km})$ $(\mathrm{km})$

\begin{tabular}{|c|c|c|c|}
\hline \multirow[b]{2}{*}{ Education (respondent only) } & \multicolumn{3}{|c|}{ Kendall-Tau-b } \\
\hline & -.008 & .060 & -.085 \\
\hline $\begin{array}{l}\text { I regularly read articles about } \\
\text { ecological issues in } \\
\text { newspapers and magazines }\end{array}$ & -.125 & -.088 & .081 \\
\hline $\begin{array}{l}\text { I am very interested to } \\
\text { watch reports on ecological } \\
\text { issues in TV and radio }\end{array}$ & -.022 & -.034 & .138 \\
\hline $\begin{array}{l}\text { Environmental consumption is } \\
\text { very important regarding } \\
\text { energy }\end{array}$ & .014 & .057 & .120 \\
\hline $\begin{array}{l}\text { Environmental consumption is } \\
\text { very important regarding travel } \\
\text { and mobility }\end{array}$ & $.194\left(\left(^{*}\right)\right.$ & .148 & $.343\left(^{* *}\right)$ \\
\hline $\begin{array}{l}\text { Environmental consumption } \\
\text { is very important regarding food }\end{array}$ & -.078 & -.049 & .045 \\
\hline $\begin{array}{l}\text { Environmental consumption is } \\
\text { very important regarding } \\
\text { waste }\end{array}$ & -.074 & -.081 & .045 \\
\hline $\begin{array}{l}\text { Many friends of mine are } \\
\text { interested in environmental } \\
\text { issues }\end{array}$ & .027 & -.070 & .121 \\
\hline $\begin{array}{l}\text { Many friends of mine do not own } \\
\text { a car }\end{array}$ & $.199\left(^{*}\right)$ & .089 & $.369\left(^{* *}\right)$ \\
\hline $\begin{array}{l}\text { Many friends of mine prefer } \\
\text { organic food }\end{array}$ & .074 & -.108 & .082 \\
\hline
\end{tabular}

${ }^{* *}$ Correlation is significant at the 0.01 level (2-tailed). *Correlation is significant at the 0.05 level (2-tailed). 
$r=.897)$. Households with high air travel mileage score high in $\mathrm{CO} 2$ emissions. It seems that air travel (measured in $\mathrm{km}$ per household) is not dependent on other (observed) variables. It is neither a factor of settlement attributes nor of individual attributes of the respondents. All in all, only few individual factors correlate with measured environmental behaviour. As Table 14 shows there is an empirical relationship between environmental awareness concerning travel and the actual car mileage per year. In addition, it seems that households with low car mileage have more friends who do not own a car as well. Other sociological variables, like education, level of information, or specific indicators of environmental awareness, show absolutely no correlation.

\section{Discussion}

Our main findings can be summarized as follows:

1. The car-free housing project has lower $\mathrm{CO}_{2}$ emissions, measured per household, per capita, or per $€$ spent, than the reference settlement. Both settlements have lower emissions than the Austrian average, which can be explained by the lower income and factors related to larger family size, the use of district heating, and lower mobility needs. Avoiding car use is the most important reason for reduced $\mathrm{CO}_{2}$ emissions, but the purchase of green electricity is also important. The emissions of a household in the carfree settlement connected to ground transportation and energy are less than half of those in the reference settlement.

2. There are higher levels of environmental concerns in the car-free settlement, and its residents seek information on environmental issues. They also have more social contacts and there is more cohesion in the car-free settlement. These factors seem to contribute to reduced car use, but only social cohesion and social contacts are significantly correlated with reduced per capita $\mathrm{CO}_{2}$ emissions. Environmental behaviour in general and the avoidance of car use in particular seem to be important issues of discussion. We conclude that this social climate tends to reinforce environmentally friendly behaviour.

3. The emissions connected to the remaining household purchases are substantial and in fact dominate the overall HEI of both settlements. For the Austrian average, household energy use and ground transportation account for nearly half of the total HEI, but these values are lower for residents of the reference settlement and probably for Vienna in general, both because of the heating infrastructure and denser housing and because of the higher importance of public transport for daily transport needs. The high importance of these items and the higher income in the car-free settlement explain why the difference in per capita $\mathrm{CO}_{2}$ emissions is only $7 \%$. This indicates that it is important to assess all household purchases, not only a selected few.

4. Air transport has the highest emissions intensity of all purchases assessed. For the car-free settlement, air transport is responsible for more than twice the $\mathrm{CO}_{2}$ emissions of ground transportation plus energy. The distances are slightly higher than in the reference settlement, but close to the average Austrian household. From the interviews and the survey, we have no indication that vacation destinations are subject to the environmental discussions in the car-free settlement. The results also show that there is no empirical correlation between income and air transport. Moreover, there is no indication that the money saved from not owning a car is systematically diverted to air travel.

5. It was our hypothesis that environmentally conscious consumption behaviour in the car-free settlement would extend to other areas of behaviour as well. We did not find a difference in the consumption of organic food, which was high in both settlements. For other types of behaviour, our survey was too coarse. We did not find satisfactory ways to identify differences in the consumption of food - an important category. We did not attempt to assess recycling behaviour, because it has relatively little impact on $\mathrm{CO}_{2}$ emissions. For the 'other' category, the input-output analysis treats fairly broad classes of goods as homogeneous commodities. The environmental differences between buying hand-made wooden toys and massproduced electronic toys cannot be distinguished - both have the same emissions coefficient per unit expenditure. The hypothesis could hence neither be confirmed nor falsified.

In the following, we would like to discuss the merit of our novel approach, as well as the lessons to be drawn for sustainable consumption.

Our approach allows for a calculation of total household environmental impact from evidence collected by a 1-hour interview and reference to utility bills. With that, HEI assessment can be developed into a routine assessment tool for environmental projects and policy, taking into account more than the specific aspects of a project and hence is able to quantify part of the rebound effect. We feel fairly confident about the emissions calculations for transport and energy, because we had access to utility bills and we judge the information we received on car mileage and holiday destinations to be reliable. Errors for individual households should not be larger than $+/-20 \%$, and errors for the settlement averages are correspondingly smaller.

Variations in the composition of other expenditure, from food to services and toys, are much more difficult to capture. The commodity groups in the input-output analysis probably mask significant differences in the emissions intensity of individual items. It is simply unknown whether systematic differences in consumer preferences of these items can indeed affect the overall HEI. Bottom-up calculations of different dishes (Carlsson-Kanyama et al., 2003), for example, show that there can be substantial differences. Whether these are also borne out in diets of real people is unclear. Analyses of consumer expenditure surveys using energy or emissions intensities derived from input-output analysis cannot identify significant differences in HEI apart from the factors of car ownership and house type which we have included (Hertwich, 2005c; Peters et al., 2006).

The study shows that the two settlements are indeed fairly similar. This was of course part of the study design. The aspect 
in which they differ is the car-free feature. Tenants in the carfree settlement show a higher level of environmental awareness, and this awareness is translated to ecologically sound travel behaviour regarding ground transport (extensive use of bicycles and public transport for daily needs), the purchase of green electricity, but not air transport.

A number of interesting results was derived from investigating the motivational and social aspects and differences between the two settlements. For example, the study shows a significant difference in the social cohesion between the two settlements. Some have argued that social interaction can lead to lifestyle satisfaction which can reduce the desire for consumption (Kempton, 1993). It could be that the innovative features of the car-free settlement, with much space and social institutions (e.g., a listserv) to interact, play an important role in contributing to satisfaction with the chosen lifestyle. The social cohesion can also contribute to social pressure and social reinforcement of ecological behaviour. These features, however, could also be a result of the genesis of the project and the self-selection of tenants, although both settlements are theme settlements and had the opportunity to influence the settlement characteristics.

\section{Conclusions}

This study indicates that the car-free housing project has indeed lower $\mathrm{CO}_{2}$ emissions, measured per household, per capita, or per $€$ spent, than the reference settlement. Both avoiding car use and purchasing green electricity are effective in reducing the respective $\mathrm{CO}_{2}$ emissions in the car-free settlement. The emissions saved from not using a car are higher than those from buying green electricity. The two settlements have lower emissions than the Austrian average, which can be explained by the lower income and factors related to larger family size, the use of district heating, and lower mobility needs. Due to the importance of air transport and of the residual expenditure categories estimated by the input-output analysis, the difference in $\mathrm{CO}_{2}$ emissions between the two settlements is small. More detailed data on nutrition and other expenditure would be needed to confirm that there is indeed no systematic difference in the remaining expenditure categories.

Moving to the car-free settlement is not the main reason that people do not use a car anymore. Many residents have decided to live without a car long before they moved to the carfree settlement. Nevertheless, the issue 'car-use' in the carfree settlement is still a very important conversational topic in the settlement. This contributes to the stabilization of the carfree habit of the tenants. It seems that residents in the car-free settlement have changed their daily mobility routines permanently. Most of the daily mobility needs are covered by public transport and by bicycle. The ecologically conscious microculture in the car-free settlement helps to reproduce and stabilize these habits on a daily basis.

What we can learn from this investigation for the stabilization of more sustainable consumption patterns is that both factors social climate and infrastructure are important for facilitating behavioural change. In addition, the growth of air travel can easily offset gains from reduced car use. The results presented here underestimate the relative impact of air transport on climate change, since it neglects the important effects of water emissions at high altitudes (Royal Commission on Environmental Pollution, 2002). Other studies have highlighted the contribution of air transport to the environmental impact of transportation (Norland et al., 2005).

We have demonstrated that the sustainability of consumption patterns of specific populations can be studied without administering a full-scale consumer expenditure survey, and that interesting results can be obtained. A combination of lifecycle analysis and input-output analysis is required to study the emissions, and the approach should be informed by using available statistical information on household consumption patterns. Improving the sustainability of consumption patterns requires looking at the impact of the entire household consumption and investigating the underlying motivations and constraints to behaviour set by infrastructure and habits.

\section{Acknowledgements}

This research was funded by the Austrian National Bank and the Society of Non-Traditional Technology in Japan. The project was hosted at the International Institute for Applied Systems Analysis (IIASA) in Laxenburg, Austria. We would like to thank Atsushi Inaba (AIST, Tsukuba, Japan) for continuous support of our research efforts and Yuri Ermoliev and Leen Hordijk for graciously removing administrative hurdles. Two reviewers provided valuable feedback.

\section{R E F E R E N C E S}

Aasness, J., Biorn, E., Skjerpen, T., 1993. Engel functions, panel-data, and latent-variables. Econometrica 61 (6), 1395-1422.

Alberti, M., 1996. Measuring urban sustainability. Environmental Impact Assessment Review 16 (4-6), 381-424.

Barrell, J., Whitehouse, J., 2004. Home zones — an evolving approach to community streets. Proceedings of the Institution of Civil Engineers. Municipal Engineer 157 (4), 257-265.

Beer, T., Grant, T., Brown, R., Edgward, J., Nelson, P., Watson, H., Williams, D., 2000. Life-cycle emissions analysis of alternative fuels for heavy vehicles. CSIRO Atmospheric Research Report C/0411/1.1/F2. CSIRO, Aspendale, Australia.

Briceno, T., Stagl, S., 2006. The role of social processes for sustainable consumption. Journal of Cleaner Production 14 (17), 1541-1551.

Brohmann, R., Fritsche, U., Hartard, S., Schmied, M., Schmitt, C., Schoenfelder, C., Schuett, N., Roos, W., Stahl, H., Timpe, C., Wiegmann, K., 2002. Sustainable Districts on Urban Areas: Material Flow Analyses as an Instrument for Evaluation - End Report (German). Oeko-Institut, Darmstadt. (Institute for Applied Ecology e.V.).

Bullard III, C.W., Herendeen, R.A., 1975. Energy impact of consumption decisions. Proceedings of the IEEE 63, 484-493.

Carlsson-Kanyama, A., Ekstrom, M.P., Shanahan, H., 2003. Food and life cycle energy inputs: consequences of diet and ways to increase efficiency. Ecological Economics 44 (2-3), 293-307.

Cervero, R., 2003. City carshare - first-year travel demand impacts. Transportation Finance, Economics and Economic Development, pp. 159-166. 
Eurostat, 2001. Nameas for air emissions - results of pilot studies. Office for Official Publications of the European Communities, Luxembourg.

Frischknecht, R., 2004. Ecoinvent, v.1.1. Eco-Invent Centre, Zürich.

Fritsche, U.R., 2002. Nachhaltige stadtteile-die rolle des warenkorbs der konsumenten. In: Scherhorn, G., Weber, C. (Eds.), Nachhaltiger konsum: Auf dem weg zur gesellschaftlichen verankerung. ökonom verlag, Munich.

Glotz-Richter, M., 1995. Living without a car. World Transport Policy and Practice 1 (1), 45-47.

Gutmann, R., Havel, M., 2000. Post-occupancy survey of the car-free housing project in Wien-Floridsdorf (in german). Vienna.

Haas, W., Hertwich, E.G., Hubacek, K., Korytarova, K., Ornetzeder, M., Weisz, H., 2005. The environmental impacts of consumption: research methods and driving forces. IIASA Interim Report 05/ 027. International Institute for Applied Systems Analysis, Laxenburg, Austria.

Hanssen, O.J., 1998. Environmental impacts of product systems in a life cycle perspective: a survey of five product types based on life cycle assessment studies. Journal of Cleaner Production 6, 299-311.

Herendeen, R.A., 1978. Total energy cost of household consumption in Norway, 1973. Energy 3, 615-630.

Herendeen, R.A., Tanaka, J., 1976. Energy cost of living. Energy 1, 165-178.

Hertwich, E.G., 2005a. Consumption and the rebound effect: an industrial ecology perspective. Journal of Industrial Ecology 9 (1-2), 85-98.

Hertwich, E.G., 2005b. Consumption and industrial ecology. Journal of Industrial Ecology 9 (1-2), 1-6.

Hertwich, E.G., 2005c. Lifecycle approaches to sustainable consumption: a critical review. Environmental Science and Technology 39 (13), 4673-4684.

Jackson, T. (Ed.), 2006. The Earthscan Reader on Sustainable Consumption. Earthscan, London.

Kempton, W., 1993. Will public environmental concern lead to action on global warming. Annual Review of Energy and the Environment 18, 217-245.

Klotz, J., 2002. Verbrauchsausgaben-sozialstatistische ergebnisse der konsumerhebung+ cd rom. Statistics Austria, Vienna.

Kolleritsch, E., 2004. Input-output Tables 2000. Statistics Austria, Vienna.

Kronsteiner-Mann, C., Schachl, T., 2006. Privater Konsum-Vergleich der Ergebnisse der Konsumerhebung 2004/2005 mit den volkswirtschaftlichen Gesamtrechnungen 2005. Statistische Nachrichten 2006 (11), 1069-1077.

Lenzen, M., 2001. A generalised input-output multiplier calculus for Australia. Economic Systems Research 13 (1), 65-92.

Lenzen, M., Dey, C., Foran, B., 2004. Energy requirements of Sydney households. Ecological Economics 49 (3), 375-399.

Lenzen, M., Wier, M., Cohen, C., Hayami, H., Pachauri, S., Schaeffer, R., 2006. A comparative multivariate analysis of household energy requirements in Australia, Brazil, Denmark, India and Japan. Energy 31 (2-3), 181-207.

Loose, W., Mohr, M., Nobis, C., 2006. Assessment of the future development of car sharing in Germany and related opportunities. Transport Reviews 26 (3), 365-382.

MA5, 2006. Statistical data - Vienna by district Vienna City Government. http://www.wien.gv.at/statistik/daten/ bezirksdaten html2006accessed 27.10.2006.

Malinvaud, E., 1980. Statistical Methods of Econometrics. North-Holland, Amsterdam.

Moll, H.C., Noorman, K.J., Kok, R., Engström, R., Throne-Holst, H. Clark, C., 2005. Bringing about more sustainable consumption patterns: analyzing and evaluating the household metabolism in European countries and cities. Journal of Industrial Ecology 9 (1-2), 259-276.

Mont, O., 2004. Institutionalisation of sustainable consumption patterns based on shared use. Ecological Economics 50 (1-2), 135-153.
Munksgaard, J., Pedersen, K.A., Wier, M., 2000. Impact of household consumption on $\mathrm{CO} 2$ emissions. Energy Economics 22 (4), 423-440.

Nijdam, D.S., Wilting, H.C., Goedkoop, M.J., Madsen, J., 2005. Environmental load from Dutch private consumption: how much damage takes place abroad? Journal of Industrial Ecology 9 (1-2), 147-168.

Nobis, C., 2003. The impact of car-free housing districts on mobility behaviour - case study. In: Beriatos, E., Brebbia, C.A., Coccossis, H., Kungolos, A. (Eds.), Sustainable Planning \& Development. WIT Press, Southampton, Boston.

Norland, I.T., Holden, E., Lafferty, W.M., 2005. Consumption of energy and transport in urban households: the role of urban planning vs. 'green consumerism' in promoting sustainable consumption. In: Hertwich, E.G., Briceno, T., Hofstetter, P., Inaba, A. (Eds.), Sustainable Consumption: The Contribution of Research, 2005/1. Norwegian University of Science and Technology, Trondheim.

Peters, G., Hertwich, E.G., 2004. Production Factors and Pollution Embodied in Trade: Theoretical Development. WP 2004/5. Norwegian University of Science and Technology, Trondheim. Industrial Ecology Program.

Peters, G.P., Hertwich, E.G., 2006. The importance of import for household environmental impacts. Journal of Industrial Ecology 10 (3), 89-110.

Peters, G.P., Aasness, J., Holck-Steen, N., Hertwich, E.G., 2006. Environmental impacts and household characteristics: an econometric analysis of Norway 1999-2001. Proceedings, Sustainable Consumption Research Exchange, Wuppertal.

Preisendörfer, P., 2001. Sozialprofil und Lebenslage von Haushalten ohne Auto. Kölner Zeitschrift für Soziologie und Sozialpsychologie 53 (4), 734-750.

Prettenthaler, F.E., Steininger, K.W., 1999. From ownership to service use lifestyle: the potential of car sharing. Ecological Economics 28 (3), 443-453.

Priemus, H., 2005. How to make housing sustainable? The Dutch experience. Environment and Planning. B, Planning and Design 32, 5-19.

Ravetz, J., 2000. Integrated assessment for sustainability appraisal in cities and regions. Environmental Impact Assessment Review 20 (1), 31-64.

Royal Commission on Environmental Pollution, 2002. The Environmental Effect of Civil Aircraft in Flight. Royal Commission on Environmental Pollution, London.

Scheurer, J., 2001. Urban Ecology, Innovations in Housing Policy and the Future of Cities: Towards Sustainability in Neighbourhood Communities. Murdoch University, Perth, Australia.

Schweimer, G.W., Levin, M., 1999. Sachbilanz des Golf A4. Mit Bilanzplänen und Ergebnistabellen. Volkswagen, Wolfsburg. Z 99.519 .501 .00

Stokes, D., Lindsay, A., Marinopoulos, J., Treloar, A., Wescott, G., 1994. Household carbon-dioxide production in relation to the greenhouse-effect. Journal of Environmental Management 40 (3), 197-211.

Tukker, A., Jansen, B., 2006. Environment impacts of products - a detailed review of studies. Journal of Industrial Ecology 10 (3), 159-182.

Udo de Haes, H.A., Jolliet, O., Finnveden, G., Goedkoop, M., Hauschild, M., Hertwich, E.G., Hofstetter, P., Klöpffer, W. Krewitt, W., Lindeijer, E.W., Mueller-Wenk, R., Olson, S.I., Pennington, D.W., Potting, J., Steen, B., 2002. Life Cycle Impact Assessment: Striving Towards Best Practice. Society of Environmental Toxicology and Chemistry, Pensacola. United Nations General Assembly, 1992. Agenda 21. United Nations Division for Sustainable Development, Rio de Jainero.

United Nations General Assembly, 2002. World Summit on Sustainable Development: Plan of Implementation. United Nations Division for Sustainable Development, Johannesburg. 
Vringer, K., Blok, K., 1995. The direct and indirect energy requirements of households in the Netherlands. Energy Policy 23 (10), 893-910.

Wallisch, A., 2004. Personal Communication.

Wiener Linien, 2004. Alles über uns: Betriebsangaben 2003 Wiener Linien.

Wier, M., Lenzen, M., Munksgaard, J., Smed, S., 2001. Effects of

household consumption patterns on $\mathrm{CO} 2$ requirements. Economic Systems Research 13 (3), 259-274.
Wright, C., Curtis, B., 2005. Reshaping the motor car. Transport Policy 12 (1), 11-22.

Zacharias, J., 2003. The search for sustainable transport in a developing city - the case of Tianjin. International Development Planning Review 25 (3), 283-299. 